\title{
Histomorphological Changes in Kidney Associated with the Ethanolic Extracts of the Leaves of Phyllanthus amarus in Cadmium Induced Kidney Damage in Experimental Animals
}

\author{
Ogunnaike Philip Olubunmi ${ }^{1}$, Olatunji Sunday Yinka ${ }^{1,2, *}$, Owolabi Joshua Oladele ${ }^{1}$, \\ Olanrewaju Afees John ${ }^{1}$, Baderinwa Deborah Boluwatife ${ }^{1}$ \\ ${ }^{1}$ Department of Anatomy, Ben Carson Senior School of Medicine, Babcock University, Ilisan Remo, Nigeria \\ ${ }^{2}$ Department of Anatomy and Cell Biology, Obafemi Awolowo University, Ile-Ife, Nigeria
}

\author{
Email address: \\ olatunjis@babcock.edu.ng (O. S. Yinka) \\ ${ }^{*}$ Corresponding author
}

\section{To cite this article:}

Ogunnaike Philip Olubunmi, Olatunji Sunday Yinka, Owolabi Joshua Oladele, Olanrewaju Afees John, Baderinwa Deborah Boluwatife. Histomorphological Changes in Kidney Associated with the Ethanolic Extracts of the Leaves of Phyllanthus amarus in Cadmium Induced Kidney Damage in Experimental Animals. International Journal of Clinical and Developmental Anatomy. Vol. 3, No. 4, 2017, pp. $25-35$. doi: 10.11648/j.ijcda.20170304.12

Received: September 6, 2017; Accepted: September 28, 2017; Published: October 23, 2017

\begin{abstract}
Heavy metal poisoning is often as a result of prolonged occupational or domestic exposure to toxic metals and it is difficult to treat it immediately as the effects manifest over time. The use of herbal medicines and phytonutrients continues to expand rapidly across the world with many people now resorting to these products for treatment of various health challenges in different national healthcare settings. Chanca Piedra is a plant that has proven useful in assisting the treatment of various diseases. There have also been controversial claims on the effects of the plant on kidney stones and gall stones. Since cadmium is a very common nephrotoxic agent to which humans and animals are exposed frequently, this study has the potential to provide insight into the possible prophylactic and ameliorative effects of Chanca Piedra on kidney damage and it may also help in providing solutions to the problem of cadmium nephrotoxicity. The present study was carried out to investigate the prophylactic and ameliorative effects of orally administered ethanolic extract of Chanca Piedra (CP) (Phyllantus amarus) against nephrotoxicity produced by cadmium $(40 \mathrm{mg} / \mathrm{kg} \mathrm{BW})$ sulphate in adult male Wistar rats (Rattus novegicus). Forty-two (42) adult male Wistar rats were used in this study and were divided into seven (7) groups of $(n=6)$ as follows: Group A (control), Group B (40mg $/ \mathrm{kg} \mathrm{BW})$, Group C $(100 \mathrm{mg} / \mathrm{kg} \mathrm{BW}$ of CP $+40 \mathrm{mg} / \mathrm{kg} \mathrm{BW})$, Group D $(200 \mathrm{mg} / \mathrm{kg}$ BW of CP + $40 \mathrm{mg} / \mathrm{kg} \mathrm{BW}$ ), Group E (40mg/kg BW + 100 $\mathrm{mg} / \mathrm{kg}$ BW of CP), Group F (40mg/kg BW + 200mg $/ \mathrm{kg} \mathrm{BW}$ of CP), Group G $(200 \mathrm{mg} / \mathrm{kg} \mathrm{BW}$ of CP). Both cadmium and Chanca piedra were administered orally through oro-gastric cannula. The animals were sacrificed 24 hours after the last administration through cervical dislocation and blood samples were collected through cardiac puncture for analysis of superoxide dismutase and glutathione peroxidase and the kidney were fixed in $10 \%$ formal saline for $24 \mathrm{hrs}$ and then processed for histological analysis. Histological analysis using H\&E stain for general histoarchitecture and Masson's Trichrome for collagen fibres, indicated alterations in cell morphology of all the treated groups. The findings indicated that the administration of $\mathrm{CP}$ extract has no prophylactic or ameliorative effects on Cd-induced kidney damage and that $\mathrm{CP}$ had observable adverse effects on the kidneys of adult Wistar rats.
\end{abstract}

Keywords: Chanca Piedra, Phyllanthus amarus, Kidney Damage, Nephrotoxicity, Cadmium

\section{Introduction}

Heavy metal poisoning is mostly as a result of prolonged occupational or domestic exposure to toxic metals which

can be difficult to treat immediately as the effects manifest over time and therefore many attempts have been made to 
overcome heavy metal poisoning [1]. The use of herbal medicines and phytonutrients continues to expand rapidly across the world with many people now resorting to these products for treatment of various health challenges in different national healthcare settings [2].

Chanca piedra (Phyllantus amarus) is a small, erect, annual herb that grows $30-40 \mathrm{~cm}$ in height. It is indigenous to the Amazon rainforests and other tropical areas in the world, including the Bahamas, southern India, and China. Chanca Piedra is quite prevalent in the Amazon and other wet rainforests, growing and spreading freely (much like a weed). The Spanish name of the plant, chanca piedra, means "stone breaker" or "shatter stone." This plant was named for its effective use to generations of Amazonian indigenous peoples in eliminating kidney stones and gall stones and it is also employed for other conditions including diabetes, malaria, dysentery, fever, flu, tumors, colic, jaundice, vaginitis, and dyspepsia. Plants contain numerous constituents; and some tend to possess some level of toxicity. Cases of toxicity in plants have been reported $[3,4,5]$. Chanca Piedra has been classified among plants with a low potential for toxicity, with an LD50 averaging $2000 \mathrm{mg} / \mathrm{kg} /$ day [6]. The role of Chanca piedra in the treatment of diseases associated with free radicals and oxidative stress have been suggested and tested with various positive results $[6,7,8]$. In this research, the efficacy of Chanca Piedra against heavy metal poisoning produced by cadmium was tested for its prophylactic and ameliorative effects at different doses. Cadmium toxicity has been demonstrated in several organs. Cadmium induces tissue injury through creating oxidative stress [9, 10, 11], epigenetic changes in DNA expression [12, 13, 14], inhibition or upregulation of transport pathways $[15,16$, 17], particularly in the proximal segment of the kidney tubule [18]. Other pathologic mechanisms include competitive interference with the physiologic action of $\mathrm{Zn}$ or $\mathrm{Mg}[19,20,21]$, inhibition of heme synthesis [22] and impairment of mitochondrial function potentially inducing apoptosis [23], The clinical manifestation of cadmium toxicity depends on route, quantity, and rate of exposure. Some of the reported clinical manifestations of cadmium accumulation in the human body includes: Carcinogenesis, neurodegeneration, lung dysfunction, renal dysfunction, vascular disease, hypertension, coronary heart disease, myocardial infarction, anemia, osteoporosis, Parkinson's disease, and Azeimer's disease [24]. Agricultural products are a major source of cadmium in the human diet. The pathway of human exposure from agricultural crops is susceptible to increases in soil cadmium as increase in soil cadmium contents result in an increase in the uptake of cadmium by plants. The most important sources of cadmium to agricultural soils are atmospheric deposition and direct inputs through the application of phosphate fertilizers and other soil amendment products. Some of the regulative focal points in many countries have being decreasing the cadmium content of fertilizers and restriction on the input of cadmium to farmland by application of sewage sludge and other waste products [25]. Average daily intakes from food in most areas not polluted with cadmium are 10-40 $\mu \mathrm{g}$ [25]. In polluted areas the value has been found to be several hundred $\mu \mathrm{g}$ per day. In non-polluted areas, uptake from heavy smoking may equal cadmium intake from food. There is now a consensus among scientists to say that in chronic $\mathrm{Cd}$ poisoning the kidney, which is the main storage organ of $\mathrm{Cd}$, is also the critical target organ, i.e. the first organ to display signs of toxicity [26, 27, 28]. Cd nephropathy has been described in industrial workers exposed mainly by inhalation and in the general population exposed via contaminated foods. The various studies conducted on human populations and experimental animals have demonstrated that $\mathrm{Cd}$ exerts its renal toxicity in a strictly dose-dependent manner, the adverse effects occurring only when the Cd concentration in kidney cortex reaches a critical threshold. The total concentration of $\mathrm{Cd}$ in renal cortex from which renal effects are likely to occur has been estimated at $150-200 \mathrm{ppm}(\mu \mathrm{g} / \mathrm{g}$ wet weight of renal cortex), both in human subjects and in experimental animals [26, 28]. Herbal and dietary substances than can be used to ameliorate the toxic effects of heavy metals are being sought and presently, no information is available on the effects of Chanca piedra on Cd-induced nephrotoxicity which is the reason for this research. Chanca Piedra is a plant that has been reported to have ameliorative properties in the treatment of various diseases. There have also been some controversial claims on the effects of this plant on kidney stones and gall stones. Since cadmium is a very common nephrotoxic agent which humans and animals come in contact with daily from various sources, a study like this will shed more light on the possible prophylactic effects and ameliorative effects of Chanca Piedra on kidney damage and as well help in providing solutions to the problem of cadmium nephrotoxicity.

\section{Materials and Methods}

\subsection{Plant Extract}

The Chanca piedra (C.P) leaves were collected from gardens and surroundings of Babcock University, Ilishan Remo, Ogun State in Nigeria. The collected plants were taken to the Botany Department of Obafemi Awolowo University, Ife, Osun State for identification and later authenticated at the Herbarium with a reference number. The plant extraction was carried out at the Department of Pharmacology, Babcock University.

The leaves were cleaned, air-dried for 2 weeks after which it was pulverized into dry powder using industrial laboratory grinder. Extraction of the phytochemicals was done by soaking $104 \mathrm{~g}$ of the powder in $500 \mathrm{ml}$ of $50 \%$ ethanol for 72 hours after which the extract was filtered using a white moslin cloth. Crude extract was obtained by filtration followed by concentration of the solvent in an oven at $40^{\circ} \mathrm{C}$ and the evaporation of the plant gave rise to a paste. The paste was 
weighed and $10 \mathrm{~g}$ of the paste was dissolved in $400 \mathrm{ml}$ of distilled water for the preparation of the stock solution.

\subsection{Substance of Use}

The cadmium sulphate was obtained from Sigma Aldrich ${ }^{\circledR}$ USA and $5 \mathrm{~g}$ of Cadmium sulphate was dissolved in $200 \mathrm{ml}$ of distilled water and administered daily at a dosage of $40 \mathrm{mg} / \mathrm{kg}$ body weight through oral cannula throughout the period of administration.

\subsection{Animal Care and Treatment}

Forty-two, (42) adult male Wistar rats (Rattus norvegics) between 150-200g were purchased from the disease-free stock of the Babcock University animal house and were left to acclimatize for one week. They were assigned into seven groups on the basis of their weight: A, B, C, D, E, F and G of $(n=6)$ in each group.

The rats were bred with plastic cages with wire screen tops, they were kept under adequate ventilation with room temperature and relative humidity of $29+2^{\circ} \mathrm{C}$ and $40-70 \%$, respectively, with a $12 \mathrm{hr}$ natural light-dark cycle. Pelleted feed and water was given to the animals and good hygiene was maintained by constant cleaning and removal of urine and faeces with spilled feed from cages daily.

Table 1. Treatment Protocol.

\begin{tabular}{ll}
\hline Groups & Treatment \\
\hline A & Control: distilled water only \\
B & Cadmium sulphate $(40 \mathrm{mg} / \mathrm{kg}$ body weight $)$ only \\
C & Chanca piedra $(100 \mathrm{mg} / \mathrm{kg}$ body weight $)+$ Cadmium sulphate $(40 \mathrm{mg} / \mathrm{kg}$ weight $)$ for the next $14 \mathrm{days}$ \\
D & Chanca Piedra $(200 \mathrm{mg} / \mathrm{kg}$ body weight $)+$ Cadmium sulphate $(40 \mathrm{mg} / \mathrm{kg}$ weight $)$ for the next 14 days \\
E & Cadmium sulphate $(40 \mathrm{mg} / \mathrm{kg}$ body weight $)$ for 14 days + Chanca Piedra $(100 \mathrm{mg} / \mathrm{kg}$ body weight $)$ for the next14 days \\
F & Cadmium sulphate $(40 \mathrm{mg} / \mathrm{kg}$ body weight $)$ for 14 days + Chanca Piedra( $(200 \mathrm{mg} / \mathrm{kg}$ body weight $)$ for the next 14 days \\
G & Chanca Piedra $(200 \mathrm{mg} / \mathrm{kg}$ body weight $)$ only \\
\hline
\end{tabular}

\subsection{Experimental Etiquette}

The protocol of experimentation was according to the guide to the care and use of animals in research and teachings approved by the Babcock University Human Research Ethic Committee (BUHREC).

\subsection{Sacrifice and Organ Harvest}

At the end of the 28 days administration, the animals were sacrificed through cervical dislocation and blood samples were collected through cardiac puncture. Dissection was done through abdominal incision on to expose the abdominal contents of the abdominal cavity; the organs were displaced using a pair of forceps and the kidneys were taken from the posterior abdominal wall of the animal and fixed in $10 \%$ formal saline for $24 \mathrm{hrs}$ and then processed for histological analysis.

\subsection{Histology Analysis}

Haematoxylin and Eosin method was used to demonstrate the general histology and morphology of the kidney of the control and treated groups. The sections were examined under a LEICA research microscope (LEICA DM750, Switzerland) interfaced with digital camera (LEICA ICC50). Digital photomicrographs of stained sections of the kidney structure were taken at various magnifications.

\subsection{Statistical Analysis}

Data were expressed as Mean \pm Standard Error of Mean (S.E.M). The statistical significant was evaluated by one way analysis of variance (ANOVA) using GraphPad Prism5 (Version 5.03, GraphPad Inc.) followed by Student NewanKeuls (SNK) test for multiple comparisons. A value of $p<$
0.05 was considered statistically significant.

\section{Results}

\subsection{Plasma Superoxide Dismutase Level in Control and Treated Groups}

\section{PLASMA SUPEROXIDE DISM UTASE}

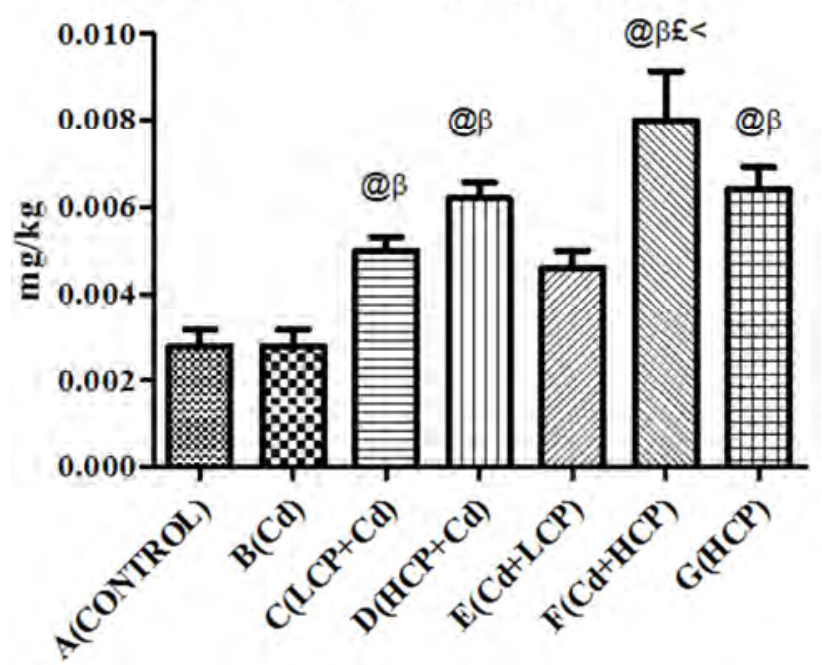

Figure 1. Plasma Superoxide Dismutase Level ( $\mathrm{mg} / \mathrm{kg})$. Values are Mean \pm SEM of Data Obtained; @ = Significantly Different from A (control); $\beta=$ Significantly Different from $B(C d) ;<=$ Significantly Different from $C(L C P$ $+C d) ; £=$ Significantly Different from $E(C d+L C P):(p<0.05)$. Cadmium (Cd), Low dose of Chanca Piedra + Cadmium $(L C P+C d)$, High dose of Chanca Piedra + Cadmium $(H C P+C d)$, Cadmium + Low dose of Chanca Piedra $(C d+L C P)$, Cadmium + High dose of Chanca Piedra $(C d+H C P)$, High dose of Chanca Piedra (HCP).

Figure 1 shows the result of the plasma Superoxide dismutase level of the animals across the groups. The plasma 
superoxide dismutase level in groups $\mathrm{C}(\mathrm{LCP}+\mathrm{Cd})(0.0050$ $\pm 0.0003), \mathrm{D}(\mathrm{HCP}+\mathrm{Cd})(0.0062 \pm 0.0004), \mathrm{F}(\mathrm{Cd}+\mathrm{HCP})$ $(0.0080 \pm 0.0011), \mathrm{G}(\mathrm{HCP})(0.0064 \pm 0.0005)$ were significantly $(\mathrm{p}<0.05)$ higher when compared to the control group A $(0.0028 \pm 0.0004)$. The plasma superoxide dismutase level in groups $\mathrm{C}(\mathrm{LCP}+\mathrm{Cd})(0.0050 \pm 0.0003)$, $\mathrm{D}(\mathrm{HCP}+\mathrm{Cd})(0.0062 \pm 0.0004), \mathrm{F}(\mathrm{Cd}+\mathrm{HCP})(0.0080 \pm$ $0.0011), \mathrm{G}(\mathrm{HCP})(0.0064 \pm 0.0005)$ were also significantly $(\mathrm{p}<0.05)$ higher when compared to Group B $(\mathrm{Cd})(0.0028 \pm$ $0.0004)$. Groups E (Cd + HCP) $(0.0046 \pm 0.0004)$ and F $(\mathrm{Cd}$ $+\mathrm{HCP})(0.0080 \pm 0.0011)$ plasma superoxide dismutase level were significantly $(\mathrm{p}<0.05)$ higher than group $\mathrm{C}(\mathrm{LCP}+\mathrm{Cd})$ $(0.0050 \pm 0.0003)$.

\subsection{Plasma Glutathione Peroxidase Level in Control and Treated Groups}

\section{PLASMA GLUTATHIONE PEROXIDASE}

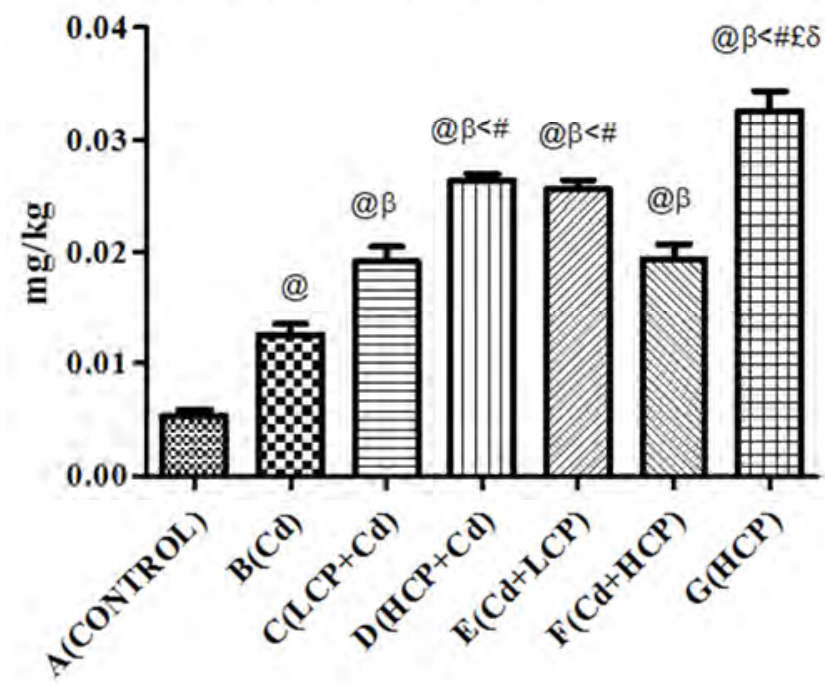

Figure 2. Plasma Glutathione Peroxidase Level ( $\mathrm{mg} / \mathrm{kg}$ ) Values are $\mathrm{mEan} \pm$ SEM of Data Obtained; @ = Significantly Different from A (control); $\beta=$ Significantly Different from $B(C d) ;<=$ Significantly Different from $C(L C P$ $+C d) ; \delta=$ Significantly Different from $D(H C P+C d) ; £=$ Significantly Different from $E(C d+L C P)$; \# = Significantly Different from $F(C d+H C P)$ : ( $p<0.05)$. Cadmium (Cd), Low dose of Chanca Piedra + Cadmium (LCP + $\mathrm{Cd})$, High dose of Chanca Piedra + Cadmium $(\mathrm{HCP}+\mathrm{Cd})$, Cadmium + Low dose of Chanca Piedra $(C d+L C P)$, Cadmium + High dose of Chanca Piedra $(\mathrm{Cd}+\mathrm{HCP})$, High dose of Chanca Piedra (HCP).

Figure 2 shows the result of the plasma Glutathione peroxidase level in the animals across the groups. The plasma Glutathione Peroxidase levels in groups B $(\mathrm{Cd})(0.0126 \pm$ $0.0009), \mathrm{C}(\mathrm{LCP}+\mathrm{Cd})(0.0192 \pm 0.0013), \mathrm{D}(\mathrm{HCP}+\mathrm{Cd})$ $(0.0264 \pm 0.0006), \mathrm{E}(\mathrm{Cd}+\mathrm{LCP})(0.0256 \pm 0.0008), \mathrm{F}(\mathrm{Cd}+$ $\mathrm{HCP})(0.0194 \pm 0.0014)$ and $\mathrm{G}(\mathrm{HCP})(0.0326 \pm 0.0018)$ were significantly $(\mathrm{p}<0.05)$ higher than the control group A $(0.0054 \pm 0.0005)$. The plasma Glutathione Peroxidase levels in Groups C $(\mathrm{LCP}+\mathrm{Cd})(0.0192 \pm 0.0013), \mathrm{D}(\mathrm{HCP}+\mathrm{Cd})$ $(0.0264 \pm 0.0006), \mathrm{E}(\mathrm{Cd}+\mathrm{LCP})(0.0256 \pm 0.0008), \mathrm{F}(\mathrm{Cd}+$ HCP) (0.0194 \pm 0.0014$)$ and G (HCP) (0.0326 \pm 0.0018$)$ were also significantly $(\mathrm{p}<0.05)$ higher than Group B $(\mathrm{Cd})$ $(0.0126 \pm 0.0009)$. The plasma Glutathione Peroxidase level in groups $\mathrm{D}(\mathrm{HCP}+\mathrm{Cd})(0.0264 \pm 0.0006), \mathrm{E}(\mathrm{Cd}+\mathrm{LCP})$ $(0.0256 \pm 0.0008)$ and $\mathrm{G}(\mathrm{HCP})(0.0326 \pm 0.0018)$ were also significantly $(\mathrm{p}<0.05)$ higher when compared to Group $\mathrm{C}$ $(\mathrm{LCP}+\mathrm{Cd})(0.0192 \pm 0.0013)$. Group G (HCP) $(0.0326 \pm$ 0.0018) plasma Glutathione Peroxidase level was also significantly $(\mathrm{p}<0.05)$ higher when compared to Groups D $(\mathrm{HCP}+\mathrm{Cd})(0.0264 \pm 0.0006)$ and $\mathrm{E}(\mathrm{Cd}+\mathrm{LCP})(0.0256 \pm$ $0.0008)$. The plasma Glutathione Peroxidase levels in groups $\mathrm{D}(\mathrm{HCP}+\mathrm{Cd})(0.0264 \pm 0.0006), \mathrm{E}(\mathrm{Cd}+\mathrm{LCP})(0.0256 \pm$ $0.0008)$ and $\mathrm{G}(\mathrm{HCP})(0.0326 \pm 0.0018)$ were significantly $(\mathrm{p}$ $<0.05)$ higher when compared to Group F $(\mathrm{Cd}+\mathrm{HCP})$ $(0.0194 \pm 0.0014)$.

\subsection{Histological Results}

Figure 3 shows the cortex of the kidney under lower magnification (100x) with identifiable glomerulus and urinary space, however in slides $\mathrm{D}(\mathrm{HCP}+\mathrm{Cd})$ and $\mathrm{F}(\mathrm{Cd}+$ $\mathrm{HCP}$, degeneration in the glomerulus was observed accompanied with increase in the size of the urinary space when compared to the control group. No visible alterations were observed in group $\mathrm{E}(\mathrm{Cd}+\mathrm{LCP})$. In figure $3 \mathrm{G}(\mathrm{HCP})$, larger urinary space was also observed when compared to control but the spaces were not as large as groups D (HCP + Cd) and HCP. Figures 4 and 5 showed the cortex of the kidney under higher magnification (400x). In the control group, the Glomerulus, Proximal Convoluted Tubule, Distal Convoluted Tubule, Glomerulus and Podocytes are clearly observable. The cadmium treated group B showed large degeneration in the podocytes, large urinary space, degeneration of the cells of the PCT and DCT. In group C $(\mathrm{LCP}+\mathrm{Cd})$, shows distortion of PCT. Group D $(\mathrm{HCP}+\mathrm{Cd})$ presented with degenerated Glomerulus, large Urinary Space and degenerated lumen. The general histology of the kidney in this group was distorted as the PCT and DCT were not easily identified. In the Chanca piedra treated group, there was slight degeneration of the Glomerulus and larger urinary space when compared to the control group. The PCT and DCT were observable as this did not show any histological distortions. The group with the largest histological distortions when compared to the control group and other groups is Group D $(\mathrm{HCP}+\mathrm{Cd})$. 

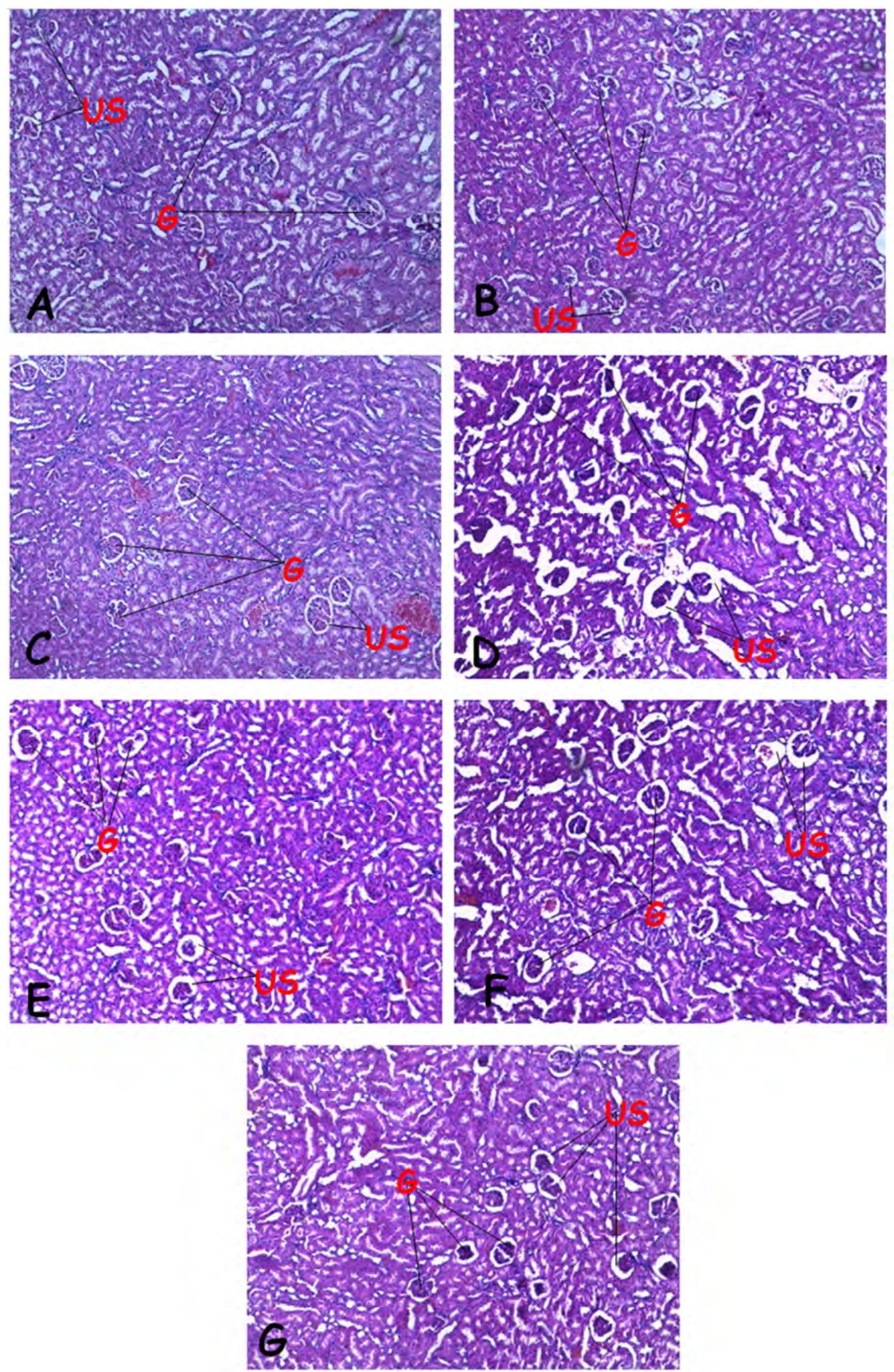

Figure 3. Photomicrographs of the Cortex of the Kidney Stained with $H \& E(100 X)$. $A=G r o u p A$ (Control), $B=G r o u p ~ B(C d), C=G r o u p C(L C P+C d), D=$ Group $D(H C P+C d), E=$ Group $E(C d+L C P), F=\operatorname{Group} F(C d+H C P), G=$ Group $G(H C P)$. Glomerulus $(G)$, Urinary Space (US). 

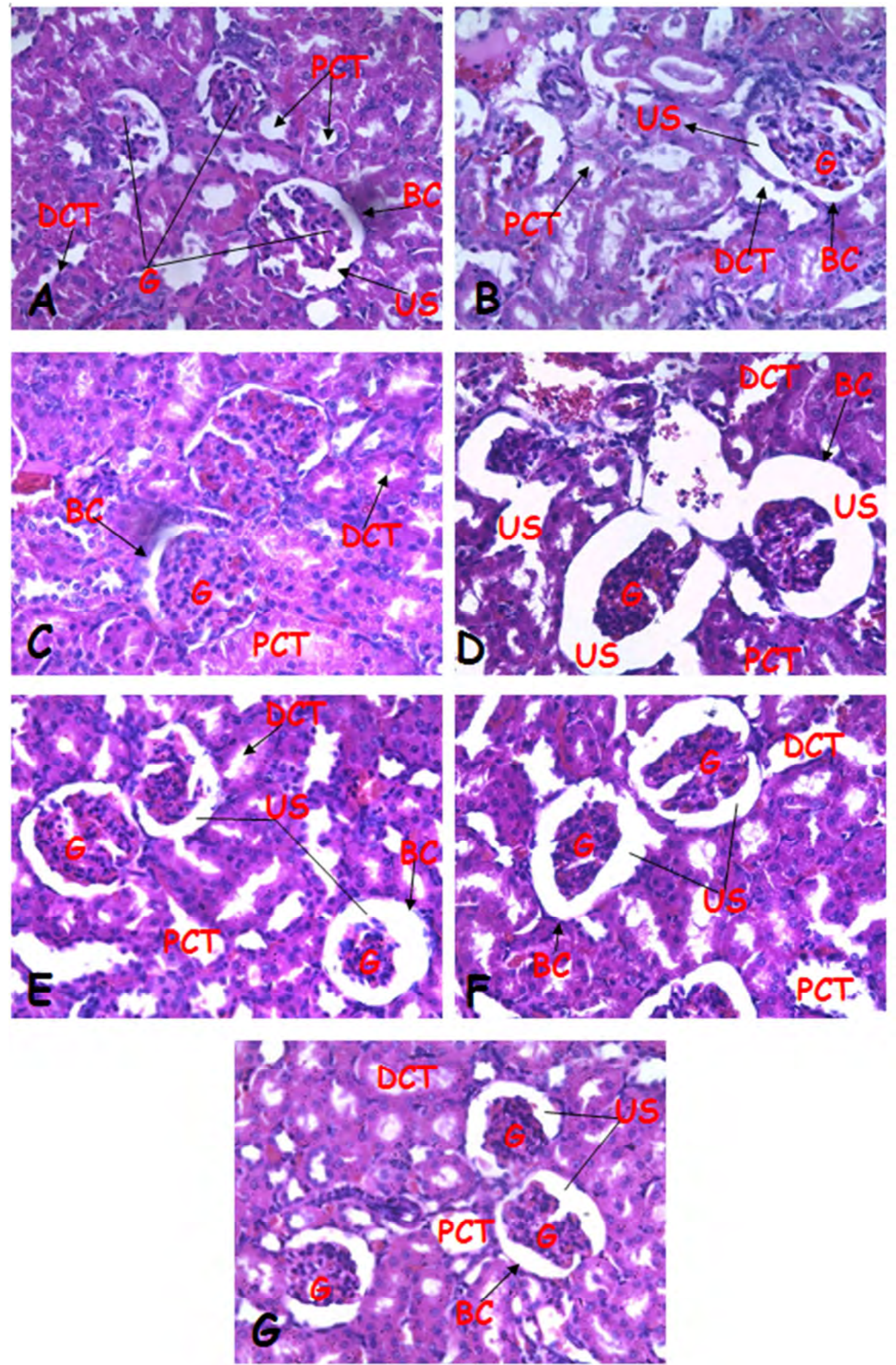

Figure 4. Photomicrographs of the Cortex of the Kidney Stained with $H \& E(400 X) . A=G r o u p A($ Control), $B=G r o u p ~ B(C d), C=G r o u p C(L C P+C d), D=$ Group D $(H C P+C d), E=$ Group $E(C d+L C P), F=$ Group $F(C d+H C P), G=$ Group $G(H C P)$. Glomerulus $(G)$, Urinary Space (US), Bowman's Capsule (BC), Proximal Convoluted Tubule (PCT), Distal Convoluted Tubule (DCT). 

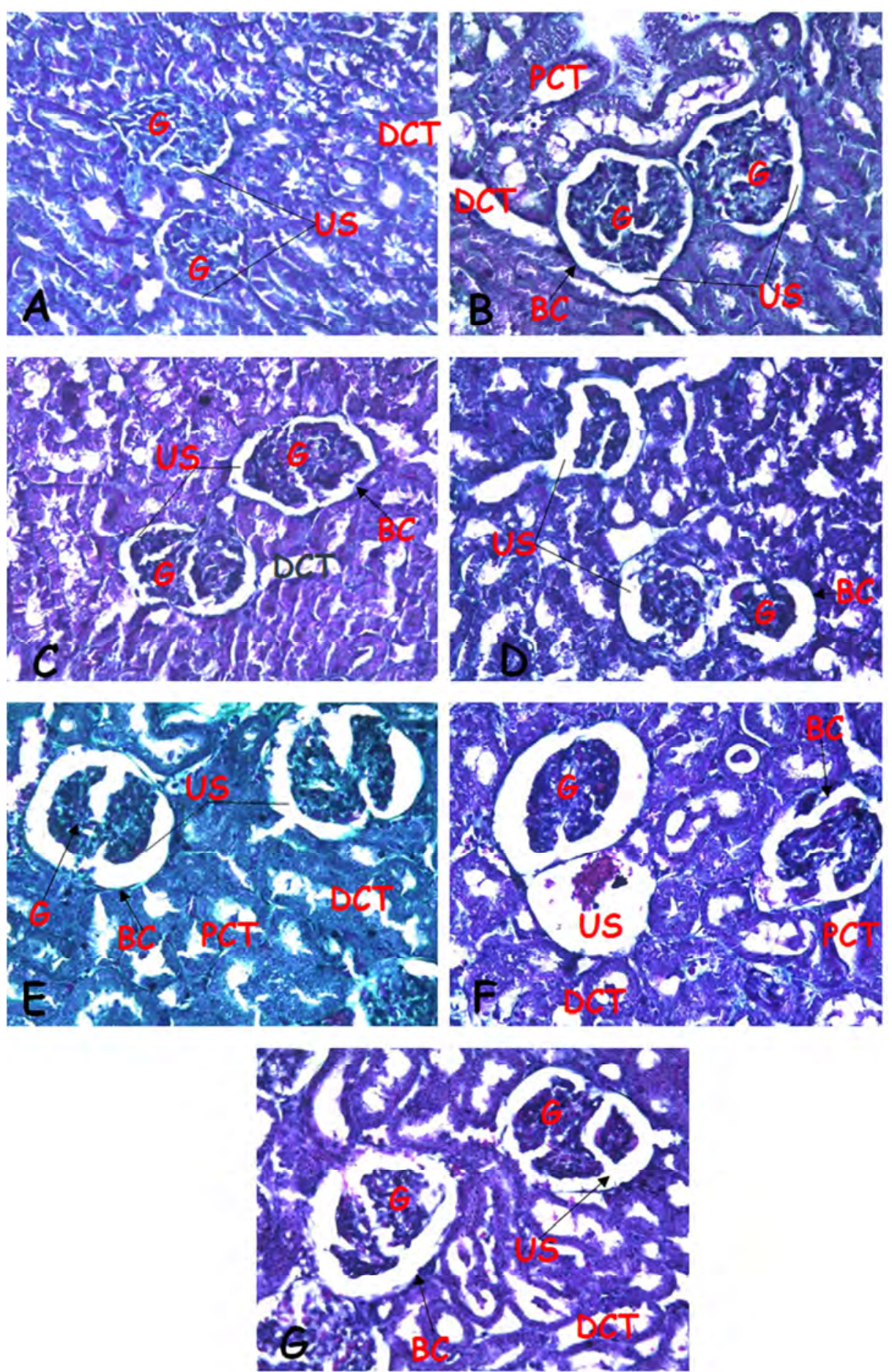

Figure 5. Photomicrographs of the Cortex of the Kidney Stained with Masson's Trichrome (400X). A= Group A (Control), B=Group B (Cd), C=Group C $(L C P+C d), D=$ Group D $(H C P+C d), E=$ Group E $(C d+L C P), F=$ Group F $(C d+H C P), G=$ Group G (HCP). Glomerulus $(G)$, Urinary Space (US), Bowman's Capsule (BC), Proximal Convoluted Tubule (PCT), Distal Convoluted Tubule (DCT).

\section{Discussion}

There are many studies to back up the detrimental effects of heavy metal poisoning by cadmium on human health due to the occupational or domestic exposure to the metal through everyday human activities, such as tobacco smoking, mining, smelting and refining of non-ferrous metals, fossil fuel combustion, incineration of municipal waste (especially cadmium-containing batteries and plastics), manufacture of phosphate fertilizers, and recycling of cadmium-plated steel scrap and electric and electronic waste [10]. The kidneys play a vital role in the elimination of toxic substances thereby making them more exposed to toxic materials in relation to other organs [29]. The biochemical and histological evaluation of substances in animal models is very important in determining the potential risk for human life and it is 
necessary to ensure the safety of a medication or chemical [30]. This study investigated the effects of Chanca piedra leaf extract on some markers of renal function and the histoarchitecture of the kidney in rats with cadmium-induced kidney injury.

\subsection{Oxidative Study: Superoxide Dismutase and Glutathione Peroxidase}

According to the results in this experiments, there was a significant increase in the superoxide dismutase level of the chanca piedra treated group when compared to the control group. The cadmium group had the same level of superoxide dismutase as the control group. The chanca piedra and cadmium treated groups C $(100 \mathrm{mg} / \mathrm{kg}$ BW CP $+40 \mathrm{mg} / \mathrm{kg}$ BW Cd), D (200mg/kg BW CP + 40mg/kg BW Cd), and F $(40 \mathrm{mg} / \mathrm{kg} \mathrm{BW} \mathrm{Cd}+200 \mathrm{mg} / \mathrm{kg} \mathrm{BW} \mathrm{CP})$ also had increased superoxide dismutase level when compared to the control with group F $(40 \mathrm{mg} / \mathrm{kg} \mathrm{BW} \mathrm{Cd}+200 \mathrm{mg} / \mathrm{kg} \mathrm{BW} \mathrm{CP})$ having the highest significant $(\mathrm{p}<0.05)$ increase of superoxide dismutase concentration in the experimental groups. This may be due to the fact that the animals in group $\mathrm{F}$ were administered high dose of chanca piedra due to their body weight and experimental design. However, the superoxide dismutase level in group E $(40 \mathrm{mg} / \mathrm{kg} \mathrm{BW} \mathrm{Cd}+100 \mathrm{mg} / \mathrm{kg}$ BW CP) was slightly higher than the control group but this was not statistically $(p<0.05)$ significant. This may be due to the fact that this group received the low dose of chanca piedra during this experiment. This may also be due to the effect of the cadmium on the chanca piedra. This needs to be further investigated.

In this study, plasma Glutathione peroxidase levels in the chanca piedra treated group $G$ was significantly $(p<0.05)$ higher when compared to the control group. The chanca piedra and cadmium treated groups $\mathrm{C}(100 \mathrm{mg} / \mathrm{kg} \mathrm{BW} \mathrm{CP}+$ $40 \mathrm{mg} / \mathrm{kg} \mathrm{BW} \mathrm{Cd}), \mathrm{D}(200 \mathrm{mg} / \mathrm{kg} \mathrm{BW} \mathrm{CP}+40 \mathrm{mg} / \mathrm{kg} \mathrm{BW}$ $\mathrm{Cd}), \mathrm{E}(40 \mathrm{mg} / \mathrm{kg} \mathrm{BW} \mathrm{Cd}+100 \mathrm{mg} / \mathrm{kg} \mathrm{BW} \mathrm{CP})$ and $\mathrm{F}$ $(40 \mathrm{mg} / \mathrm{kg} \mathrm{BW} \mathrm{Cd}+200 \mathrm{mg} / \mathrm{kg} \mathrm{BW} \mathrm{CP})$ also significant increase in plasma Glutathione peroxidase level when compared to the control group A. It is important to note that the group with the highest increase in plasma Glutathione peroxidase level was group G $(200 \mathrm{mg} / \mathrm{kg}$ BW CP) which received high dose of Chanca piedra only which was followed by groups D $(200 \mathrm{mg} / \mathrm{kg} \mathrm{BW} \mathrm{CP}+40 \mathrm{mg} / \mathrm{kg} \mathrm{BW}$ $\mathrm{Cd})$ and $\mathrm{E}(40 \mathrm{mg} / \mathrm{kg} \mathrm{BW} \mathrm{Cd}+100 \mathrm{mg} / \mathrm{kg} \mathrm{BW} \mathrm{CP})$ respectively. This may be due to the fact that these groups received high dose of chanca piredra. A significant $(p<0.05)$ increase in plasma glutathione peroxidase level was also observed in the cadmium treated group. The increase plasma in superoxide dismutase and glutathione peroxidase levels in the groups that were administered chanca piedra may be due to the anti-oxidant properties which helps in the elimination of free radicals, this is in agreement with the following works $[31,32,33,3435]$.

\subsection{Histological Analysis}

In the normal histology of the kidney, under the light microscope, the Glomerulus and podocytes, Bowman's capsule, Urinary space, Proximal convoluted tubules and Distal convoluted tubules are visible.

In this study, the histology of the control group showed normal histology of the kidney. Although not all the kidney features were represented, the glomerulus and urinary space and other histological features were well observed in the control group. However, the histology of the cadmium treated group confirms the nephrotoxic effects of the cadmium evidenced by the shrinkage of the glomerulus, occlusion of the lumen of the Proximal convoluted tubule, degeneration of cells of the Proximal convoluted tubules and distal convoluted tubules, vacoulation within the nucleus and presence of plaques, increased urinary space and inflammation and degeneration of the glomerulus as shown in Figure 4B, this is consistent with earlier works [36] in which they showed cadmium causes kidney damage. These changes could also be linked to oxidative imbalances due to the presence of cadmium.

The chanca piedra and cadmium treated group $\mathrm{C}$ $(100 \mathrm{mg} / \mathrm{kg}$ BW $\mathrm{CP}+40 \mathrm{mg} / \mathrm{kg} \quad \mathrm{BW} \quad \mathrm{Cd})$ also showed distortions in the histological appearance with larger urinary spaces coupled with degeneration of the glomerulus when compared to the control group. However, the podocytes did not show any histological distortion. This shows that chanca piedra at $100 \mathrm{mg} / \mathrm{kg}$ body weight has no prophylactic effect against cadmium-induced kidney damage.

Group D (200mg/kg BW CP + 40mg/kg BW Cd) showed larger degeneration of the glomerulus and podocytes accompanied with large urinary space. Degeneration of the lumen was also observed. There was a larger distortion in the histology of group D as the proximal convoluted tubules and the distal convoluted tubules were not easily observed. This shows that chanca piedra at $200 \mathrm{mg} / \mathrm{kg}$ body weight has no prophylactic effect against cadmium-induced kidney damage. The histology of Group E also showed degeneration of the glomerulus and lumen. There was also an increase in the size of the urinary tract when compared to the control group. Also, there was also slight degeneration in the proximal convoluted tubules. This can be due to the toxic effects of the cadmium and the Chanca piedra.

Histological analysis of the Chanca piedra treated group $G$ $(200 \mathrm{mg} / \mathrm{kg}$ BW) showed a slight degeneration in the glomerulus and larger urinary space as compared to the control group. However, the proximal convoluted tubules and the distal convoluted tubules were not distorted. It can be inferred that Chanca piedra has toxic effects on the kidney.

The group with the highest amount of renal damage relative to the control is group D $(200 \mathrm{mg} / \mathrm{kg} \mathrm{BW} \mathrm{CP} \mathrm{+}$ $40 \mathrm{mg} / \mathrm{kg} \mathrm{BW} \mathrm{Cd)}$. This could be due to the fact that group D was administered High dose and Chanca piedra followed by cadmium and these two substances have been shown to possess adverse effects of the kidney histologically.

Cadmium-induced nephrotoxicity is mediated through the cadmium metallothionein (Cd-Mt) complex, which is synthesized in the liver and released into circulation. This is then taken by the renal proximal tubule cells [37]. When the 
synthesis of metallothionein becomes insufficient of binding all cadmium ions in the liver, the free cadmium ions which are not bound to Mt produce hepatocyte injury and a Cd-Mt complex is released into the blood stream. The $\mathrm{Cd}-\mathrm{Mt}$ complex in the plasma is then filtered through the glomeruli in the kidney and taken up by the proximal convoluted tubule [38]. On its way through the kidney, this complex causes injury especially in the cortical region, reaching the proximal convoluted tubule and causing a gradual loss in the kidney function [39]. These changes in this study could be linked to increased lipid peroxidation by free cadmium ions and consequence accumulation of free radicals in the renal tissue of the cadmium treated rats [40] as the mechanism of Cadmium-induced kidney damage is considered to be related to increased oxidative status increasing the formation of free radicals [41].

Chanca piedra has good antioxidant properties which help in removal of free radicals from the human body [31, 32, 33, $34,35]$, several active compounds have been identified in P. amarus extract. Lignins like phyllanthin and hypophyllanthin, flavonoids like quercetin and astragalin, ellagitannins like amarinic acid and hydrolyzable tannins like phyllanthisiin D isolated from this plant were reported to possess antioxidative properties [42]. Chanca Piedra can detoxify the free radicals and has an antioxidant activity and increase the rate of regeneration of necrosed cells [43, 44]. However, the use of these herb is limited by side effects. Chanca Piedra at high and low dosages was unable to restore the effects of cadmium damage.

There were several degeneration and necrosis of the tubular epithelial cells in the kidneys of the chanca piedra treated animals. The degenerative changes where observed more in the kidneys of rats that received the higher dose $(200 \mathrm{mg} / \mathrm{kg})$ of chanca piedra. It may be inferred from the present results that higher doses of Chanca Piedra may have resulted in degenerative changes observed in the renal cortex. The histological effects observed in this experiment is in coherance with the report of Manjrekar et al. who observed that Chanca piedra induced deleterious changes on the renal tubules rats[ 45,46$]$. It is important to note that Chanca piedra contains alkaloids and lots of antioxidants [7, 8, 9]. Although, antioxidants are essential for alleviation of oxidative stress, indiscrete intake of alkaloids and antioxidant constituents of Chanca piedra may present their toxic effects by inducing oxidative stress $[48,49]$. The possible inference from these results is that secondary metabolites, which are largely responsible for therapeutic activities of plants [50], may also account for their toxicity. The actual mechanism by which P. amarus induced cellular degeneration observed in this experiment needs further investigation.

\section{Conclusion and Recommendation}

It was observed in the present study that Chanca piedra both at high and low doses administered daily for 14 days had no prophylactic or ameliorative effects on renal damage, this however remains controversial, hence further investigation is required. Chanca piedra also caused some structural damages on the kidney. Further investigation on the isolation and identification of the active components responsible for these effects should be carried out. However, it can be said that Chanca piedra has no ameliorative or prophylactic effects on cadmium-induced kidney damage.

It is recommended that further studies aimed at corroborating these observations be carried out because Chanca piedra is used as a medication against various medical conditions but some researches have shown that it poses a threat to the kidneys and possibly other organs of the body.

\section{References}

[1] Jarup L, Rogenfelt A, and Elinder C. (1983). biological halftime of cadmium in the blood of workers ater ceasation of exposure. Scandinavian journal of work, environment and Health, 9(4), 327-331.

[2] Winston, David. (2011). Herbal and Nutritional Treatment of kidney stones. journal of the american herbalists guild, 10(2), 61 .

[3] Santos, A. R. S, Ailho, V. C, Yunes, R. A, Calixto, J. B. (1995). Analysis of the mechanism underlying the Antinociceptive Effect of the. General Pharmacol, 26, 1499-1506.

[4] Shaw, D., Leon, C., Koleu, S., Murray, V. (1997). Traditional Remedies and Food Supplements. A Five- year Toxicology Study (1991,1995). Drug Safety, 17, 342-356.

[5] Kaplowitz, N. (1997). Hepatotoxicity of Herbal Remedies. Insight into the intricacies of plant- animal warfare and Cell Death. Gastroenterology. 113, 1403-1412.

[6] Krithika R., Verma R. J. (2009). Mitigation of carbon tetrachloride-induced damage by Phyllanthus amarus in liver of mice. Acta Pol, 66(4), 439-444.

[7] Fernand V. (1998). Initial characterization of crude extracts from Phyllanthus amarus schum and thonn and Quassia amara L. using normal phase thin layer chromatography [Thesis]. Louisiana State University.

[8] Naaz, F., Javed, S., Abdin, M. Z. (2007). Hepatoprotective effect of ethanolic extract of Phyllanthus amarus Schum. et Thonn. on. J Ethnopharmacol, 113, 503-509.

[9] Matovi'c V, Buha A, Bulat Z, and Duki'c D. (2011). Cadmium toxicity revisited: focus on oxidative stress induction and interactions with zinc andmagnesium. Arhiv za Higijenu Radai Toksikologiju, 62(1), 65-76.

[10] Patra R. C, Rautray A. K, and Swarup D. (2011). oxidative stress in lead and cadmium toxicity and its amelioration. Veterinary Medicine International.

[11] Cuypers A, Plusquin M, Remans et al.,. (2010). Cadmium stress: an oxidative challenge. BioMetals, 23(5), 927-940.

[12] Wang B, Shao C, Li Y, Tan Y, and Cai L,. (2012). cadmium and its epigenetic effects. Current Medicinal Chemistry, 19(16), 2611-2620.

[13] Martinez-Zamudio. (2011). Environmental epigenetics in metal exposure. Epigenetics, 6(7), 820-827. 
[14] Luparello C, Sirchia R, and Longo A. (2011). Cadmium as atranscriptional modulator in human cells. critical reviews in toxicology, 41(1), 75-82.

[15] Thevenod F. (2010). "Catch me if you can! Novel aspects of cadmium transport inmammalian cells". biometals, 23(5), 857-875.

[16] Van Kerkhove, Pennemans V, and Swennen Q. (2010). cadmium and transport of ions and substances across cellmembranes and epithelia. boimetals, 23(5), 823-855.

[17] Wan L and Zhang H. (2012). Cadmium toxicity: effects on cytoskeleton, vesicular trafficking and cell well reconstruction. plant signalling and behaviour, 7(3), 345-348.

[18] Vesey DA. (2010). Transport pathways for cadmium in the intestine and kidney proximal tubule: focus onthe interaction with essential metals. toxicology letters, 198(1), 13-19.

[19] Abdulla M, Chmielnicka J. (1989). New aspects on the distribution and metabolism of essential trace elements after dietary exposure to toxic metals. Biological trace elements research, 23, 25-53.

[20] Moulis J. (2010). Cellular Mechanisms of Cadmium toxicity related to the homeostasis of essential metals. biometals, 23(5), 877-896.

[21] Shukla S and Singhal R. (1984). the present status of biological effects of toxic metals in the environment: lead, cadmium and manganese. canadian journal of physiology and pharmacology, 62(8), 1015-1031.

[22] Schauder A, Avital A, Malik Z. (2010). regulation and gene expression of heme synthesis under heavy metal exposurereview. journal of environmental Pathology, Toxicology and oncology, 29(2), 137-158.

[23] Cannino G, Ferruggia E, Luparello C and Rinaldi M. (2009). Cadmium and Mitochondria. 9(6), 377-384.

[24] Arisawa K, Uemera H, Hiyoshi M, Dakeshita, Kitayama A, Saito H. (2007). cause specific mortality and cancer incidence rates in relation to urinary beta2-microglobulin: 23-year follow-up study in a cadmium-polluted area. toxicology letter, 28, 168-174.

[25] World Health Organisation (WHO) (1992). Cadmium. Environmental Health Criteria 134.

[26] Nordberg G. F, Nogawa K, Nordberg M and Friberg L. (2007). cadmium. In N. K. Nordberg G. F, Handbook of toxicology of metals (3 ed., pp. 445-486). Elsevier, Amsterdam, The Netherlands.

[27] Jarup L, Berglund M, Elinder C. G, Nordberg G, Vahter M. (1998). Health effects of cadmium exposure: a review of literature and a risk estimate. Scand $J$ Work Environ Health, $1(1), 51$.

[28] Bernard A, Lauwerys R. (1986). effects of cadmium exposure in humans. In F. E. C, \& Berlin (Ed.), Handbook of expermental pharmacology (pp. 135-177). Springer-Verlag.

[29] Prozialeck W. C, Edwards J. R, Woods J. M. (2006). the vascular endothelium as a target of cadmium toxicity. Life Sciences, 79(16), 1493-1506.

[30] Asare G. A, Addo P, Bugyei K, Gyan B, Adjei S, Otu-Nyarko L. S, Wiredu E. K, Nyarko A (2011). Acute toxicity studies of aqueous leaf extract of Phyllanthus niruri. Interdiscip. Toxicol. 4: 206-210.
[31] Mhaskar, K. S., Blatter, E. \& Caius, J. F. (2000). Kirtikar and Basu's Illustrated Indian Medicinal Plants, vol. 9. Sri Satguru Publications, Delhi, India, p.3074.

[32] Raphael, K. R. \& Kuttan, R. (2003). Inhibition of experimental gastric lesion and inflammation by Phyllanthus amarus extract. Journal of Ethnopharmacology, 87: 193-197.

[33] Londhe, J. S., Devasagayam, T. P. A., Foo, L. Y. \& Ghaskadbi, S. S. (2009). Radioprotective Properties of Polyphenols from Phyllanthus amarus Linn. Journal of radiation research, 50: 303-309.

[34] Harikumar, K. B., Kuttan, G. \& Kuttan, R. (2009). Inhibition of viral carcinogenesis by Phyllanthus amarus. Integrative Cancer Therapies, 8(3):254-60.

[35] Rai, V., Khatoon, S., Rawat, A. K. S. \& Mehrotra, S. (2007). Disruption of elements uptake due to excess chromium in indian medicinal plants. Biological Trace Element Research, 120: $127-132$

[36] Ogunnaike Philip Olubunmi, Olatunji Sunday Yinka, Owolabi Joshua Oladele, Fabiyi Adetutu Olubusayo, Olanrewaju John Afees (2016). An Assessment of Renal Function Parameters on the Ameliorative Properties of Ginkgo Biloba Extract in Cadmium-Induced Nephrotoxicity in Adult Wistar Rats Model. American Journal of Clinical and Experimental Medicine. Vol. 4, No. 4, 2016, pp. 112-117. doi: 10.11648/j.ajcem.20160404.15.

[37] Dudley R. E, Gammal L. M, Klaassen C. D (1985). Cadmiuminduced hapatic and renal inury in chronically exposed rats: likely role of hepatic cadmium-metallothionein in nephrotoxicity. Toxicology and Applied Pharmacology 77 (3): 414-426.

[38] Sudo J, Hayashi T, Kimura S, Kakuno K, Terui J, Takashima K, Soyama M. (1996). Mechanism of nephrotoxicity induced by repeated administration of Cadmium chloride in rats. Journal of Toxicology and Environmental Health 48 (4): 333348 .

[39] Thijssen S, Maringwa J, Faes C, Lambrichts I, Kerkhove E. V. (2007). Chronic exposure of mice to environmentally relevant, low doses of cadmium leads to early renal damage, not predicted by blood or urine cadmium levels. Toxicology 229 (2): $145-156$.

[40] Renugadevi J, Lamas M, Martin D, Islas S, Luna J (2012) Naringenin protects against cadmium-induced oxidative renal dysfunction in rats. Toxicol 256: 128-134.

[41] Tang W and Shaikh Z. A. (2001). Renal cortical mitochondrial dysfunction upon cadmium metallathionein administration to sprague-dawley rats. J Toxicol Environ Health - Part A. 63 (3): 221-235.

[42] Foo L. Y and Wong H. (1992). phyllanthusin D, an unusual hydrolysable tannin from phyllanthus amarus. Phytochemistry, 31, 711-713.

[43] Tagrajan, S. P., Jayaram, S. \& Villicammai, T. (1990). Phyllanthus amarus and hepatitis-B. Lancet, 336: 949-950.

[44] Oudhia, P. \& Tripthi, R. S. (2002). Prospects of cultivation of medical plants in Chhattisgarh India. Recent progress in medical plants vol. 5 crop improvement production technology, trade and commerce. Sci. Thch. Pub. USA.; pp 211-236. 
[45] Manjrekar, A. P., Jisha, V., Bag, P. P., Adhikary, B., Pai, M. M., Hegde, A., et al., (2008). Effect of Phyllanthus niruri Linn treatment on liver, kidney and testes in $\mathrm{CCl} 4$ induced hepatotoxic rats. Indian J Exp Biol. 46: 514-520. 20.

[46] Adedapo, A. A., Adegbayibi, A. Y., Emikpe, B. O. (2005). Some clinico-pathological changes associated with the aqueous extract of the leaves of Phyllanthus amarus in rats.

[47] Varoni M. V, Palomba D, Gianorso S, Anania V. (2003). Cadmium as an environmental factor of hypertension in animals: new perspectives on mechanisms. Veterinary Research communications, 27(1), 807-810.
[48] Atici, S., Cinel, I., Cinel, L., Doruk, N., Eskandari, G., Oral, U. (2005). Liver and kidney toxicity in chronic use of opioids: An experimental long term treatment model. J Biosci; 30: 245-252.

[49] Galati, G., O'Brien, P. J. (2004). Potential toxicity of flavonoids and other dietary phenolics: significance for their chemopreventive and anticancer properties. Free Radic Biol Med.; 37: 287-303.

[50] Perry, L. M. (1980). Medicinal plants of East and South-East Asia, MIT Press, Cambridge Massachusetts. 